\title{
Effect of Hydrogen Peroxide on Prostaglandin Production and Cellular Integrity in Cultured Porcine Aortic Endothelial Cells
}

\author{
A. R. Whorton, M. E. Montgomery, and R. S. Kent \\ Divisions of Clinical Pharmacology and Cardiology, Departments of Pharmacology and Medicine, Duke University Medical Center, \\ Durham, North Carolina 27710
}

\begin{abstract}
Oxidative damage to the vascular endothelium may play an important role in the pathogenesis of atherosclerosis and aging, and may account in part for reduced vascular prostacyclin $\left(\mathrm{PGI}_{2}\right)$ synthesis associated with both conditions. Using $\mathrm{H}_{2} \mathrm{O}_{2}$ to induce injury, we investigated the effects of oxidative damage on PGI $_{2}$ synthesis in cultured endothelial cells (EC). Preincubation of $\mathrm{EC}$ with $\mathrm{H}_{2} \mathrm{O}_{2}$ produced a dose-dependent inhibition (inhibitory concentration $\left[\mathrm{IC}_{50}\right]=35 \mu \mathrm{M}$ ) of $\mathrm{PGI}_{2}$ formation from arachidonate. The maximum dose-related effect occurred within $1 \mathrm{~min}$ after exposure although appreciable $\mathrm{H}_{2} \mathrm{O}_{2}$ remained after 30 min (30\% of original). In addition, $\mathrm{H}_{2} \mathrm{O}_{2}$ produced both a time- and dose-dependent injury leading to cell disruption, lactate dehydrogenase release, and ${ }^{51} \mathrm{Cr}$ release from prelabeled cells. However, in dramatic contrast to $\mathrm{H}_{2} \mathrm{O}_{2}$ effects on $\mathrm{PGI}_{2}$ synthesis, loss of cellular integrity required doses in excess of $0.5 \mathrm{mM}$ and incubation times in excess of $1 \mathrm{~h}$. The superoxide-generating system, xanthine plus xanthine oxidase, produced a similar inhibition of $\mathbf{P G I}_{2}$ formation. Such inhibition was dependent on the generation of $\mathrm{H}_{2} \mathrm{O}_{2}$ but not superoxide in that catalase was completely protective whereas superoxide dismutase was not. $\mathrm{H}_{2} \mathrm{O}_{2}(50 \mu \mathrm{M})$ also effectively inhibited basal and ionophore A23187 (0.5 $\mu \mathrm{M})$-stimulated $\mathrm{PGI}_{2}$ formation. However, $\mathrm{H}_{2} \mathrm{O}_{2}$ had no effect on phospholipase $A_{2}$ activity, because ionophore A23187-induced arachidonate release was unimpaired. To determine the effects on cyclooxygenase and $\mathbf{P G I _ { 2 }}$ synthase, prostaglandin products from cells prelabeled with [ ${ }^{3} \mathrm{H}$ ]arachidonate and stimulated with ionophore A23187, or products formed from exogenous arachidonate were examined. Inhibition of cyclooxygenase but not $\mathbf{P G I}_{2}$ synthase was observed. Incubation of $\mathrm{H}_{2} \mathrm{O}_{2}$-treated cells with prostaglandin cyclic endoperoxide indicated no inhibition of $\mathbf{P G I}_{2}$ synthase. Thus, in EC low doses of $\mathrm{H}_{2} \mathrm{O}_{2}$ potently inhibit cyclooxygenase after brief exposure whereas larger doses and prolonged exposure are required for classical cytolytic effects. Surprisingly, PGI 2 synthase, which is known to be extremely sensitive to a variety of lipid peroxides, is not inhibited by $\mathrm{H}_{2} \mathrm{O}_{2}$. Lipid solubility, enzyme location within the EC mem-
\end{abstract}

Portions of this work were presented to the American Federation for Clinical Research on 7 May 1984, in Washington, DC, and have been published as an abstract (1984. Clin. Res. 32:217).

Address reprint requests to Dr. Whorton, Division of Clinical Pharmacology, Box 3813, Duke University Medical Center, Durham, NC 27710.

Received for publication 25 September 1984 and in revised form 14 January 1985.

J. Clin. Invest.

(c) The American Society for Clinical Investigation, Inc.

0021-9738/85/07/0295/08 \$1.00

Volume 76, July 1985, 295-302 brane, or the local availability of reducing factors may explain these results, and may be important determinants of the response of EC to oxidative stress.

\section{Introduction}

The vascular endothelium is extremely sensitive to oxidative damage mediated by reactive oxygen metabolites either released from inflammatory cells (1-3) or produced within the endothelial cell (4). Of these metabolites hydrogen peroxide $\left(\mathrm{H}_{2} \mathrm{O}_{2}\right)$ appears to be an important mediator of acute cellular injury in a variety of settings $(2,3,5)$. Such oxidative damage may play a role in the pathogenesis of atherosclerosis (6) and is postulated to contribute to the aging process $(7,8)$. Traditionally, oxidative damage in cultured endothelial cells has been assessed by markers such as ${ }^{51} \mathrm{Cr}$ release, lactate dehydrogenase $(\mathrm{LDH})^{1}$ release, or by cell detachment from culture plates (2, 3 , 9). These markers of damage are crude in that they are generally indicative of severe cell membrane disruption and cell death. More subtle, but none the less important, biochemical changes are likely to precede cell lysis and may go undetected, using these insensitive markers. One potentially significant and sensitive metabolic alteration resulting from oxidative vascular injury is the loss of prostacyclin $\left(\mathrm{PGI}_{2}\right)$ synthetic capacity. Impaired capacity to form this prostaglandin may contribute to atherogenesis and aging in that $\mathbf{P G I}_{2}$ is known to be a potent vasodilator (10), an inhibitor of platelet aggregation and adherence $(11,12)$, a cytoprotective agent (13), a regulator of cholesterol ester hydrolase activity (14), and an inhibitor of smooth muscle cell proliferation (15).

Reduced $\mathrm{PGI}_{2}$ synthetic capacity has in fact been observed to occur in atherosclerosis $(16,17)$ and with aging $(18)$, and may be mediated at least in part by the overproduction of free radicals $(8,18)$, or by the loss of protection against reactive oxygen species. The metabolism of endogenous or exogenous arachidonic acid by cyclooxygenase in seminal vesicle preparations (19), cultured endothelial cells (20), or intact perfused blood vessels (21) generates radicals which cause the rapid inactivation of the enzymes required to convert arachidonic acid to $\mathrm{PGI}_{2}$. In the perfused rabbit aorta, we have demonstrated that both cyclooxygenase and $\mathrm{PGI}_{2}$ synthase are extremely sensitive to oxidative metabolites generated during arachidonic acid metabolism or during the reduction of exogenous 15hydroperoxyarachidonate (21). The sensitivity of this enzyme system to oxidative stress, and the fact that the pattern of enzymatic inactivation is dependent on the type of oxidative

1. Abbreviations used in this paper: GCMS, gas chromatograph-mass spectrometer; HBS, Hanks' balanced salts; HPLC, high performance liquid chromatography; $\mathrm{PG}$, prostaglandin; $\mathrm{PGE}_{2}$, prostaglandin $\mathrm{E}_{2}$; $\mathrm{PGF}_{1 \alpha}, 6$-keto-prostaglandin $\mathrm{F}_{1 \alpha} ; \mathrm{PGH}_{2}$, prostaglandin cyclic endoperoxide; $\mathrm{PGI}_{2}$, prostacyclin; $\mathrm{LDH}$, lactate dehydrogenase. 
metabolite present (21), suggested to us that inhibition of arachidonic acid cascade enzymes might be a very sensitive indicator of oxidative endothelial cell injury and might approximate more closely the result of those oxidative stresses in vivo that result in subtle cellular injury but not in gross cell membrane disruption.

To address this hypothesis, we have examined the effects of oxidative stress on the metabolism of arachidonic acid in cultured endothelial cells and have compared these results with those obtained by employing ${ }^{51} \mathrm{Cr}$ release, $\mathrm{LDH}$ release, and cell morphology as end points of oxidative injury. We have used $\mathrm{H}_{2} \mathrm{O}_{2}$ as the injurious agent because endothelial cells have been shown to be particularly sensitive to $\mathrm{H}_{2} \mathrm{O}_{2}$ induced injury.

\section{Methods}

Materials. Arachidonic acid, xanthine, xanthine oxidase, superoxide dismutase, catalase, glucose oxidase, and type I collagenase were purchased from Sigma Chemical Co., St. Louis, MO. Culture medium (medium 199 with Hanks' salts and phenol red indicator), Hanks' salts with and without $\mathrm{Mg}^{2+}$ and $\mathrm{Ca}^{2+}$, antibiotic/antimycotic mixture $(10,000 \mathrm{U}$ of penicillin, $10,000 \mu \mathrm{g}$ of streptomycin, and $25 \mu \mathrm{g}$ of fungizone $/ \mathrm{ml})$, trypsin $(0.5 \mathrm{~g} /$ liter)-EDTA $(0.2 \mathrm{~g} /$ liter $)$ solution, and sterile sodium bicarbonate $(7.5 \%)$ were obtained from Grand Island Biological Co., Grand Island, NY. Fetal calf serum was obtained from HyClone Laboratories, Logan, UT. Ionophore A23187 was obtained from Calbiochem-Behring Corp., San Diego, CA. Hydrogen peroxide (30\% solution, analytical grade) was obtained from Mallinckrodt, Inc., St. Louis, MO. Radiolabeled chromium $\left[{ }^{51} \mathrm{Cr}\right]$ sodium chromate and $\left[5,6,8,9,11,12,14,15-{ }^{3} \mathrm{H}\right]$ arachidonic acid were obtained from New England Nuclear, Boston, MA; $\left[3,3,4,4,-{ }^{2} \mathrm{H}\right] 6-$ keto-prostaglandin $F_{1 \alpha}$ $\left(\mathrm{PGF}_{1 \alpha}\right)$ from the Upjohn Co., Kalamazoo, $\mathrm{MI}$, and [3,3,4,4${ }^{2} \mathrm{H}$ ]prostaglandin $\mathrm{E}_{2}\left(\mathrm{PGE}_{2}\right)$ from Merck Sharp \& Dohme, Montreal, Quebec. All solvents were of high performance liquid chromatography (HPLC) grade and all derivatizing reagents were of the highest quality available.

Prostaglandin (PG) analysis. Deuterated internal standards (600$800 \mathrm{ng}$ ) were added to media collected from cell cultures after an experiment. Samples were acidified to $\mathrm{pH} 3$ with formic acid and PGs extracted with ethyl acetate ( 1 vol three times). Combined extracts were evaporated to dryness under $\mathrm{N}_{2}$ at $30-40^{\circ} \mathrm{C}$, redissolved in 0.1 $\mathrm{ml}$ of methanol, and treated with ethereal diazomethane $(0.2 \mathrm{ml})$ for $5 \mathrm{~min}$ to form the methyl ester. After evaporation to dryness, the esters were treated with a saturated solution of methoxyamine $\mathrm{HCl}$ in pyridine $(0.3 \mathrm{ml}$ overnight a room temperature) and evaporated to dryness, and the methyl ester-methoxime extracted from the residue with diethyl ether. Samples were further derivatized by reaction with $20 \mu \mathrm{l}$ of pyridine/N,O-bis-[trimethylsilyl]-trifluoroacetamide (Pierce Chemical Co., Rockford, IL) (1:1) for $2 \mathrm{~h}$ at room temperature. The fully derivatized samples were evaporated to dryness and redissolved in hexane before analysis by selected ion monitoring (22) using a gas chromatograph-mass spectrometer ([GCMS] model 5992B; HewlettPackard, Palo Alto, CA) operated with the gas chromatograph oven at $250^{\circ} \mathrm{C}$ using a 6-ft $\times 4$-mm i.d. glass column packed with $3 \% \mathrm{OV}-1$ on 80-100 Supelcoport (Supelco, Inc., Bellefonte, PA) and a helium carrier gas flow of $25 \mathrm{ml} / \mathrm{min}$. The ion source and jet separator were maintained at $260^{\circ} \mathrm{C}$. Monitored ions (endogenous vs. deuterated) were mass/charge $(\mathrm{m} / \mathrm{z}) 598$ vs. 602 and 508 vs. 512 for the methyl ester-methoxime-trimethyl silyl ethers of 6-keto-PGF ${ }_{1 \alpha}$ and $\mathrm{PGE}_{2}$, respectively. Under the conditions above, the $\mathrm{PGE}_{2}$ derivative (both major and minor methoxime isomers) was completely resolved from the 6-keto-PGF ${ }_{1 \alpha}$ derivative by the $\mathrm{OV}-1$ column so that no contribution of ions from the 6-keto- $\mathrm{PGF}_{1 \alpha}$ derivative was found in the spectrum of the $\mathrm{PGE}_{2}$ derivative. Thus the compounds were quantitated in the same injection.
Cell culture. Endothelial cells were collected from porcine aortas and cultured as described by Jaffe et al. (23). Briefly, freshly collected aortas were cleaned, filled with $0.1 \%$ collagenase in medium 199 , sealed with clamps, and incubated at $37^{\circ} \mathrm{C}$ for $15-20 \mathrm{~min}$. Freed cells were collected, washed by centrifugation at $4^{\circ} \mathrm{C}$, and resuspended in medium 199 containing Hanks' salts, 10\% fetal calf serum, and $1 \%$ antibiotic antimycotic mixture. Cells were then plated $(400,000 /$ flask) in $25-\mathrm{cm}^{2}$ flasks (Costar, Cambridge, MA) and monitored until $\sim 50 \%$ of the cell clumps adhered. Nonadhering cells were poured off and the primary isolates were incubated in medium 199 plus $10 \%$ fetal calf serum at $37^{\circ} \mathrm{C}$. The medium was changed every $3 \mathrm{~d}$ as the cells grew to confluence. Porcine aortic endothelial cells in culture were polygonal in shape and demonstrated contact inhibition. Further identification was as previously published (24). Factor VIII antigen was demonstrated in random cultures on $\mathbf{9 0 - 9 5 \%}$ of the cells. The major contaminant, smooth muscle cells, did not reach a significant level during early passage $\left(<5^{\text {th }}\right.$ passage). Primary and subsequent cultures were treated with $0.1 \%$ trypsin-EDTA at $37^{\circ} \mathrm{C}$ and split $1: 4$ for subculture. In general, confluent cultures in the first or second passage were used, although cells have been studied after the fifth passage with no apparent difference in response. Except where noted, all incubations were carried out in air at $37^{\circ} \mathrm{C}$ in Hanks' salts solution at pH 7.4. No change in cell morphology or $\mathrm{pH}$ of the medium was observed under these conditions.

$\mathrm{H}_{2} \mathrm{O}_{2}$ concentrations were determined in culture medium by colorimetric procedures essentially according to methods published by Thurman et al. (25). Aliquots of the medium were added to $0.1 \mathrm{ml}$ of $25 \%$ trichloroacetic acid, $0.2 \mathrm{ml}$ of $10 \mathrm{mM}$ ferrous ammonium sulfate, and $0.1 \mathrm{ml}$ of $2.5 \mathrm{M}$ potassium thiocyanate. The absorbance at 480 $\mathrm{nm}$ was determined against a blank containing no sample. LDH was measured by determining first-order rate of NADH oxidation spectrometrically at $340 \mathrm{~nm}$ using pyruvate and NADH (26). Protein was measured using the Coomassie blue dye method (27).

To study the effects of $\mathrm{H}_{2} \mathrm{O}_{2}$ on endothelial cells in culture, monolayers were washed (to remove medium 199 and serum) and incubated in Hanks' balanced salts (HBS) containing varying doses of $\mathrm{H}_{2} \mathrm{O}_{2}$. The buffer containing $\mathrm{H}_{2} \mathrm{O}_{2}$ was then poured off and used to determine the $\mathrm{H}_{2} \mathrm{O}_{2}$ concentration. The cells were washed again and incubated with arachidonic acid $(5 \mu \mathrm{M})$ for $3 \mathrm{~min}$ at $37^{\circ} \mathrm{C}$. The medium was then collected, internal standards were added, and the amount of PGs was determined. The effects of superoxide were determined after incubating cells in HBS containing either xanthine (5 $\mathrm{mM})$, xanthine oxidase $(1 \mathrm{U} / \mathrm{ml})$, or both for $15 \mathrm{~min}$ at $37^{\circ} \mathrm{C}$. Superoxide dismutase $(5 \mathrm{U} / \mathrm{ml})$ and catalase $(5 \mathrm{U} / \mathrm{ml})$ were added along with xanthine and xanthine oxidase in selected experiments. After incubation the medium was poured off and analyzed for $\mathrm{H}_{2} \mathrm{O}_{2}$ concentration. Fresh HBS containing arachidonate $(5 \mu \mathrm{M})$ was added and $\mathrm{PGI}_{\mathbf{2}}$ production determined as above.

To study the effects of $\mathrm{H}_{2} \mathrm{O}_{2}$ on cell integrity, either ${ }^{51} \mathrm{Cr}$ or $\mathrm{LDH}$ release was determined in cells treated with peroxide. Cells were prelabeled by incubating confluent monolayers with $2 \mu \mathrm{Ci}$ of $\left[{ }^{51} \mathrm{Cr}\right]$ sodium chromate for $3 \mathrm{~h}$. The monolayers were washed to remove extracellular $\left[{ }^{51} \mathrm{Cr}\right]$ and fresh $\mathrm{HBS}$ with or without $\mathrm{H}_{2} \mathrm{O}_{2}$ added. Aliquots were taken at various times and the amount of ${ }^{51} \mathrm{Cr}$ released was determined by using a gamma counter. After the experiment the cells were lysed in $0.2 \%$ sodium dodecyl sulfate and the amount of label remaining was determined. To measure the release of $\mathrm{LDH}$, cells were incubated in $\mathrm{HBS}$ that contained $\mathrm{H}_{2} \mathrm{O}_{2}$. After various times the buffers were removed, the monolayers were washed, and LDH released into fresh HBS during a subsequent 15-min incubation was determined. LDH remaining in the cells was determined after lysing the cells in distilled water and freezing and thawing.

To examine the effects of $\mathrm{H}_{2} \mathrm{O}_{2}$ on phospholipase activity, endothelial cells were prelabeled by incubation overnight with $2 \mu \mathrm{Ci} /$ flask of $\left[{ }^{3} \mathrm{H}\right]$ arachidonate (24). The cells were washed to remove unincorporated label and incubated in $\mathrm{HBS}$ containing $\mathrm{H}_{2} \mathrm{O}_{2}$. After pouring off the $\mathrm{H}_{2} \mathrm{O}_{2}$, cells were stimulated with ionophore A23187 ( $1 \mu \mathrm{M}$ in buffer containing $0.5 \%$ bovine serum albumin). The amount of label released 
(primarily $\left[{ }^{3} \mathrm{H}\right]$ arachidonate, reference 24 ) was quantitated by liquid scintillation spectrometry. The pattern of distribution of label into various labeled products was determined by HPLC (24). Briefly, labeled products were extracted from the incubation buffer as described above and applied to a reverse-phase HPLC column ( $\mu$-Bondapak Phenyl; Waters Associates, Millipore Corp., Milford, MA). PGs were eluted with $23 \%$ acetonitrile and $0.1 \%$ acetic acid in $\mathrm{H}_{2} \mathrm{O}$ for $40 \mathrm{~min}$. Arachidonic acid was then eluted by a linear gradient from 23 to $90 \%$ acetonitrile and $0.1 \%$ acetic acid in $\mathrm{H}_{2} \mathrm{O}$. Flow rates were $1.0 \mathrm{ml} / \mathrm{min}$ and 1-min fractions were collected and sampled to determine distribution of label into individual compounds.

The effects on cyclooxygenase and $\mathrm{PGI}_{2}$ synthase activity were determined by incubating cells with either arachidonic acid, ionophore A23187, or prostaglandin cyclic endoperoxide $\left(\mathrm{PGH}_{2}\right)$ and measuring the quantity of $\mathrm{PGI}_{2}$ and $\mathrm{PGE}_{2}$ formed by $\mathrm{GCMS}$ procedures (see above). $\mathrm{PGH}_{2}$ was prepared as previously described (18). The amount of total PG formed after incubation with arachidonate or ionophore A23187 represents combined cyclooxygenase and $\mathrm{PGI}_{2}$ synthase activities whereas $\mathbf{P G I}_{2}$ formed from $\mathrm{PGH}_{2}$ represents $\mathrm{PGI}_{2}$ synthase activity alone.

To test for significant differences, data were analyzed by one-way analysis of variance followed by the Student-Newman-Kuels test in cases where more than two means were compared.

\section{Results}

The effects of $\mathrm{H}_{2} \mathrm{O}_{2}$ on endothelial cell monolayers were studied by preincubating cultures with varying doses of peroxide. After this pretreatment, the ability of the cells to metabolize arachidonic acid to $\mathrm{PGI}_{2}$ was determined. In these experiments $\mathrm{H}_{2} \mathrm{O}_{2}$ was found to inhibit potently the formation of $\mathrm{PGI}_{2}$ by endothelial cells. The $\mathrm{IC}_{50}$ was approximately $35 \mu \mathrm{M}$ (Fig. 1). This dose-response relationship within the range examined was not time dependent; i.e., preincubation of cells with $\mathrm{H}_{2} \mathrm{O}_{2}$ for $1 \mathrm{~h}$ did not produce any greater effect on $\mathrm{PGI}_{2}$ production than preincubation for $1 \mathrm{~min}$. The rapidity of the inhibition caused by $\mathrm{H}_{2} \mathrm{O}_{2}$ is further illustrated in Fig. 2. Again the maximum extent of inactivation was achieved within $1 \mathrm{~min}$ of pretreatment. To determine whether the time course observed might reflect rapid loss of $\mathrm{H}_{2} \mathrm{O}_{2}$ from the buffer above the monolayer, we measured the change in $\mathrm{H}_{2} \mathrm{O}_{2}$ concentration as a function of time. Compared with the time course for the inactivation of the prostaglandin cascade, the decrease in $\mathrm{H}_{2} \mathrm{O}_{2}$ concentration was much slower (Fig. 2). Approximately $30 \%$

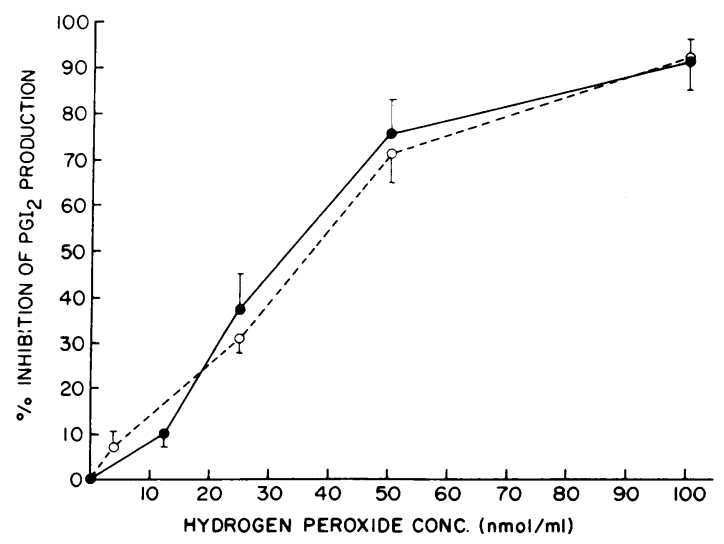

Figure 1. The effect of $\mathrm{H}_{2} \mathrm{O}_{2}$ on $\mathrm{PGI}_{2}$ formation by porcine aortic endothelial cells. Cells were preincubated for $1 \mathrm{~min}(\bullet)$ or $1 \mathrm{~h} \mathrm{(O)}$ with $\mathrm{H}_{2} \mathrm{O}_{2}$. After rinsing, the quantity of $\mathrm{PGI}_{2}$ synthesized was determined in a subsequent 3-min incubation with $5 \mu \mathrm{M}$ arachidonic acid. Data are presented as mean \pm SEM, $n=6$. of the original dose was present after $30 \mathrm{~min}$ of preincubation. Thus even after the maximum extent of inhibition of prostaglandin synthesis had occurred, significant levels of $\mathrm{H}_{2} \mathrm{O}_{2}$ remained.

The effects of $\mathrm{H}_{2} \mathrm{O}_{2}$ on cellular integrity were studied in endothelial cells prelabeled with ${ }^{51} \mathrm{Cr}$ or by measuring $\mathrm{LDH}$ release from cells pretreated with $\mathrm{H}_{2} \mathrm{O}_{2}$. In dramatic contrast to the effects of $\mathrm{H}_{2} \mathrm{O}_{2}$ on $\mathrm{PGI}_{2}$ synthesis, $\mathrm{H}_{2} \mathrm{O}_{2}$ produced both a time- and dose-dependent injury to treated cells leading to cell membrane disruption; $\mathrm{H}_{2} \mathrm{O}_{2}$ doses of at least $0.5 \mathrm{mM}$ and incubation times in excess of $1 \mathrm{~h}$ were required before sufficient damage was inflicted to allow ${ }^{51} \mathrm{Cr}$ release (Fig. 3). In fact, doses of $\mathrm{H}_{2} \mathrm{O}_{2}$ up to $1 \mathrm{mM}$ did not significantly increase release until after $60 \mathrm{~min}$. At $0.1 \mathrm{mM} \mathrm{H}_{2} \mathrm{O}_{2}$, a dose that completely inhibited $\mathrm{PGI}_{2}$ formation (Fig. 1), no significant change in ${ }^{51} \mathrm{Cr}$ release could be seen even after a 2-h incubation (Fig. 3). Thus $\mathrm{H}_{2} \mathrm{O}_{2}$-induced damage of endothelial cells exhibits a biphasic response. Low concentrations very rapidly inhibit a potentially important function of these cells ( $\mathrm{PGI}_{2}$ formation) whereas 10-20-fold higher concentrations and at least 60 -fold longer exposure are necessary to produce damage sufficient to cause cell lysis.

Similar effects on LDH release were observed. Cells were preincubated with $\mathrm{H}_{2} \mathrm{O}_{2}$ and $\mathrm{LDH}$ release determined during a subsequent incubation in medium without $\mathrm{H}_{2} \mathrm{O}_{2}$ (Fig. 4). Again, incubation times as long as $60 \mathrm{~min}$ were required to see significant changes in LDH release. Additionally, as observed with ${ }^{51} \mathrm{Cr}$ release, a sharp decrease in cellular content (increased release) occurred at $1 \mathrm{~h}$. However, in contrast to the ${ }^{51} \mathrm{Cr}$ data (Fig. 3), $\mathrm{H}_{2} \mathrm{O}_{2}$ at $1 \mathrm{mM}$ appeared to reduce total cellular $\mathrm{LDH}$ rapidly $(60 \%$ of total intracellular $\mathrm{LDH}$ remaining after 30 $\mathrm{min})$. This loss may represent release during the preincubation with $\mathrm{H}_{2} \mathrm{O}_{2}$ or inactivation of intracellular $\mathrm{LDH}$ by radicals produced in response to this high dose of peroxide.

Endothelial cell injury was also studied in monolayers incubated with the superoxide generating system, xanthine plus xanthine oxidase. In these experiments (Fig. 5), preincubation with xanthine $(0.5 \mathrm{mM})$ alone had no effect on subsequent conversion of arachidonic acid to $\mathrm{PGI}_{2}$. Xanthine oxidase $(0.1 \mathrm{U} / \mathrm{ml})$ produced a modest inhibition of $\mathrm{PGI}_{2}$ synthesis (35\%), perhaps due to the presence of endogenous endothelial xanthine or hypoxanthine (28) or to proteases that may contaminate xanthine oxidase preparations. Xanthine oxidase plus exogenous xanthine inhibited $\mathrm{PGI}_{2}$ formation by $88 \%$ (Fig. 5). Cells were not protected from these effects by co-incubation of monolayers with the superoxide-generation system plus superoxide dismutase $(5 \mathrm{U} / \mathrm{ml})$. However, the inactivation $\mathrm{PGI}_{2}$ synthesis was prevented by co-incubation of the generating system with catalase $(5 \mathrm{U} / \mathrm{ml})$ or by co-incubation of the generating system with catalase and superoxide dismutase. Thus it appears that these cells are damaged by $\mathrm{H}_{2} \mathrm{O}_{2}$ but not directly by superoxide. Neither boiled xanthine oxidase, catalase, nor superoxide dismutase alone had any effect on the conversion of arachidonate to $\mathrm{PGI}_{2}$ (data not shown). When the concentration of $\mathrm{H}_{2} \mathrm{O}_{2}$ was assayed in the medium above the cell monolayers treated with xanthine plus xanthine oxidase, significant quantities were detected (Fig. 6). As is evident from the data given in Fig. $6, \mathrm{PGI}_{2}$ formation decreased with increasing production of $\mathrm{H}_{2} \mathrm{O}_{2}$. In a similar system, $\mathrm{H}_{2} \mathrm{O}_{2}$ generated by glucose oxidase $(0.1 \mathrm{U} / \mathrm{ml})$ plus glucose $(25 \mathrm{mM})$ was effective in inhibiting the conversion of arachidonate to 


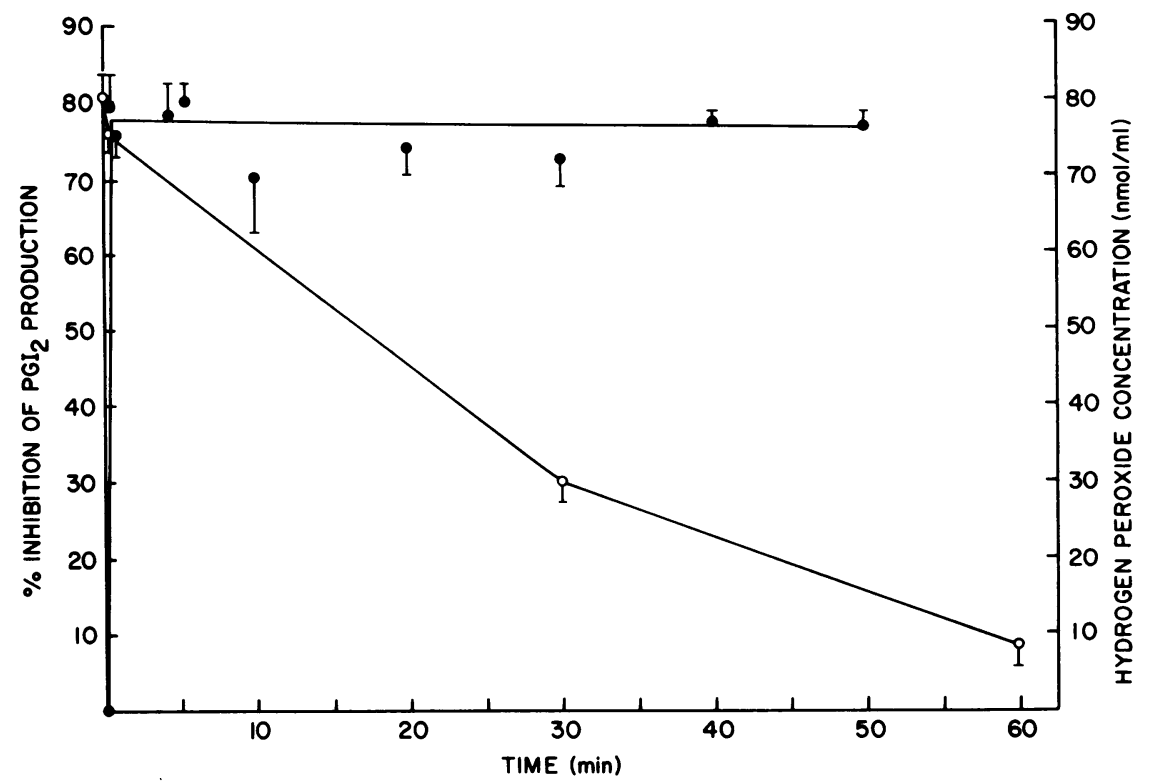

Figure 2. $\mathrm{PGI}_{2}$ synthesis and $\mathrm{H}_{2} \mathrm{O}_{2}$ degradation by endothelial cell monolayers as a function of time. Cells were preincubated with $\mathrm{H}_{2} \mathrm{O}_{2}$ (50 $\mu \mathrm{M})$, rinsed, and subsequently incubated with arachidonic acid to determine the extent of inhibition of $\mathbf{P G I}_{2}$ formation (•) (see Fig. 1). $\mathrm{H}_{2} \mathrm{O}_{2}$ concentrations $(0)$ were determined in the medium above the monolayers at the times indicated. Data given as mean \pm SEM, $n=6(\bullet)$ and $n=3(0)$.
$\mathrm{PGI}_{2}$ (98\%, data not shown) and again catalase (5 U/ml) was completely protective.

We next determined which enzyme(s) in the pathway from phospholipid to $\mathrm{PGI}_{2}$ might be inhibited by $\mathrm{H}_{2} \mathrm{O}_{2}$. Although inactivation of phospholipase seemed unlikely in that a similar inhibition of $\mathrm{PGI}_{2}$ synthesis was achieved when either exogenous arachidonic acid or ionophore A23187 was used to stimulate formation of $\mathrm{PGI}_{2}$ (Fig. 1 and Table I; $\sim 50 \%$ with $50 \mu \mathrm{M}$ $\mathrm{H}_{2} \mathrm{O}_{2}$ ), we investigated the effects of $\mathrm{H}_{2} \mathrm{O}_{2}$ on this enzyme and on cyclooxygenase and $\mathrm{PGI}_{2}$ synthase. To study changes in phospholipase activity, endothelial cell phospholipids were prelabeled by incubation overnight with $\left[{ }^{3} \mathrm{H}\right]$ arachidonate ( 1 $\mu \mathrm{Ci} / 10^{6}$ cells). Under these conditions $\sim 70 \%$ of the label was incorporated into cellular lipids, $92 \%$ of which was found in phospholipids (24). Preincubation of labeled cells with a dose of $\mathrm{H}_{2} \mathrm{O}_{2}(50 \mu \mathrm{M})$ which inhibited $\mathrm{PGI}_{2}$ synthesis by $\sim 50 \%$ (Fig. 1), had no discernible effect on phospholipase activation by ionophore A23187 (Fig. 7); i.e., equivalent amounts of

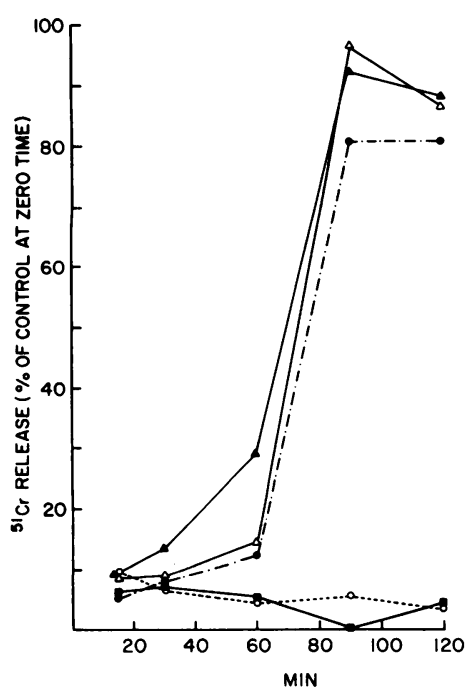

Figure 3. Effect of $\mathrm{H}_{2} \mathrm{O}_{2}$ on ${ }^{51} \mathrm{Cr}$ release from aortic endothelial cells. Confluent monolayers were prelabeled with $2 \mu \mathrm{Ci}$ of ${ }^{51} \mathrm{Cr}$, rinsed, and incubated with varying concentrations of $\mathrm{H}_{2} \mathrm{O}_{2}$.

${ }^{51} \mathrm{Cr}$ release was determined in the medium above control and $\mathrm{H}_{2} \mathrm{O}_{2}$-treated cells. Data are presented as mean of four flasks each. At 90 and $120 \mathrm{~min}$, values for 2.0 $(\triangle), 1.0(\Delta)$, and $0.5(\bullet)$ $\mathrm{mM} \mathrm{H}_{2} \mathrm{O}_{2}$ are significantly different from control (a) and $0.1(\mathrm{O}) \mathrm{mM} \mathrm{H}_{2} \mathrm{O}_{2}$ $(P<0.01)$. At $60 \mathrm{~min}, 2.0$ $\mathrm{mM} \mathrm{H}_{2} \mathrm{O}_{2}$ is different from control $(P<0.05)$. No other significant differences were observed. labeled products were released from control and $\mathrm{H}_{2} \mathrm{O}_{2}$-treated cells both basally and after ionophore stimulation. $15 \mathrm{~min}$ after stimulation with ionophore A23187, labeled products released from control (non- $\mathrm{H}_{2} \mathrm{O}_{2}$-treated) cells were analyzed by HPLC and found to be composed primarily of arachidonic acid $(63 \%, n=3), \mathrm{PGI}_{2}(21 \%)$, and $\mathrm{PGE}_{2}(16 \%)$. Labeled products released from $\mathrm{H}_{2} \mathrm{O}_{2}$-treated cells included arachidonic acid (82\%, $n=3), \mathrm{PGI}_{2}(11 \%)$, and $\mathrm{PGE}_{2}(7 \%)$. Although total amount of label released was the same for both treatments, the amounts of $\mathrm{PGI}_{2}$ and $\mathrm{PGE}_{2}$ formed decreased by $\sim 51 \%$ each. As both $\mathrm{PGI}_{2}$ and $\mathrm{PGE}_{2}$ are derived from cyclooxygenase intermediates, a similar decline in both indicates inhibition of cyclooxygenase with no inhibition of $\mathrm{PGI}_{2}$ synthase. This was confirmed by incubating control and $\mathrm{H}_{2} \mathrm{O}_{2}$-treated cells with arachidonic acid, ionophore $\mathrm{A} 23187$, or $\mathrm{PGH}_{2}$ and measuring the amount of $\mathrm{PGI}_{2}$ and $\mathrm{PGE}_{2}$ produced. As shown in Table I, $\mathrm{PGI}_{2}$ and $\mathrm{PGE}_{2}$ formation from either arachidonic acid or ionophore $\mathrm{A} 23187$ was inhibited similarly by preincubation with $\mathrm{H}_{2} \mathrm{O}_{2}$ (59\% and $65 \%$, respectively). However, $\mathrm{H}_{2} \mathrm{O}_{2}$ pretreatment did not inhibit conversion of $\mathrm{PGH}_{2}$ to $\mathrm{PGI}_{2}$ by $\mathrm{PGI}_{2}$

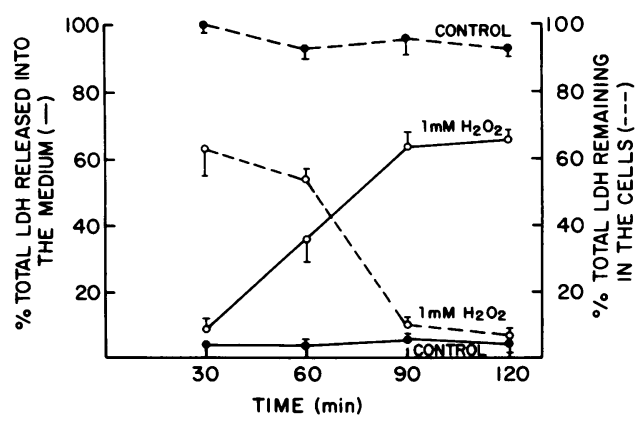

Figure 4. Effect of $\mathrm{H}_{2} \mathrm{O}_{2}$ on $\mathrm{LDH}$ release from aortic endothelial cells. Confluent monolayers were preincubated with $\mathrm{H}_{2} \mathrm{O}_{2}$ for the times indicated and rinsed to remove the peroxide. Fresh buffer was added and LDH activity remaining in the monolayers or released into the buffer determined after an additional 15-min incubation. Data are given as mean plus or minus range. 


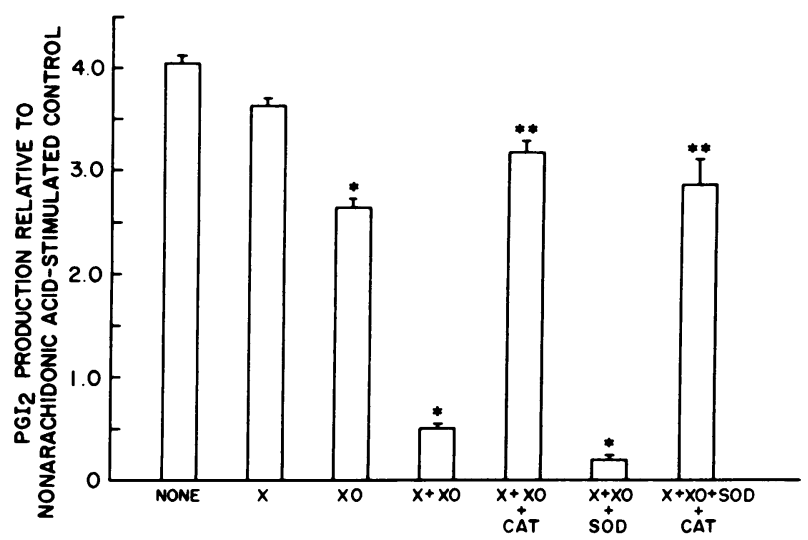

Figure 5. The effect of a superoxide generating system, xanthine (X) plus xanthine oxidase (XO), on $\mathrm{PGI}_{2}$ formation by endothelial cells. Monolayers were preincubated for 30 min with buffer alone, xanthine $(0.5 \mathrm{mM})$, xanthine oxidase $(0.02 \mathrm{U} / \mathrm{ml})$, catalase (CAT) $(5$ $\mathrm{U} / \mathrm{ml}$ ), or superoxide dismutase (SOD) $(5 \mathrm{U} / \mathrm{ml})$ in the combinations given in the figure. After rinsing, the cells were incubated for $3 \mathrm{~min}$ with $5 \mu \mathrm{M}$ arachidonic acid, and the amount of $\mathrm{PGI}_{2}$ formed was determined in the medium above the cells. Data are given as mean \pm SEM, $n=10$ (first four bars) and $n=6$ (last three bars). ${ }^{*} P<0.01$ as compared with no additions; ${ }^{* *} P<0.01$ as compared with xanthine plus xanthine oxidase or xanthine plus xanthine oxidase and superoxide dismutase.

synthase. Thus, in endothelial cell monolayers, $\mathrm{H}_{2} \mathrm{O}_{2}$ appears to inhibit cyclooxygenase but not $\mathrm{PGI}_{2}$ synthase.

Pretreatment of endothelial cells with $\mathrm{H}_{2} \mathrm{O}_{2}$ also prevented conversion of endogenous arachidonate to $\mathrm{PGI}_{2}$. When monolayers were preincubated for $10 \mathrm{~min}$ with $50 \mu \mathrm{M} \mathrm{H} \mathrm{H}_{2} \mathrm{O}_{2}$, ionophore A23187-stimulated $\mathrm{PGI}_{2}$ production was inhibited by $59 \%$ whereas ionophore A23187-stimulated $\mathrm{PGE}_{2}$ production was inhibited by $65 \%$. Basal production of $\mathrm{PGI}_{2}$ was inhibited by $28 \%$, although this reduction did not reach significance. Basal production of $\mathrm{PGE}_{2}$ was inhibited by $67 \%(P<0.05)$ (Table I).

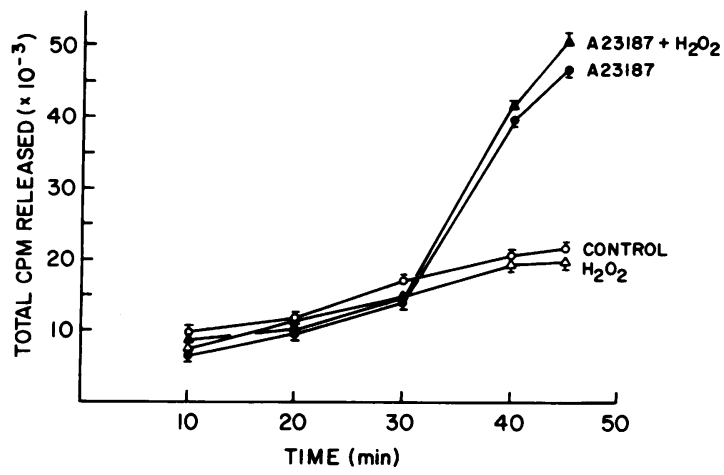

Figure 7. The effect of $\mathrm{H}_{2} \mathrm{O}_{2}$ on ionophore A23187 stimulation of arachidonic acid release. Endothelial cells were prelabeled by incubation with $\left[{ }^{3} \mathrm{H}\right]$ arachidonate. Labeled cells were then preincubated for 10 min with $50 \mu \mathrm{M} \mathrm{H}_{2} \mathrm{O}_{2}$, rinsed, and fresh buffer added. Labeled products released were determined in aliquots of medium taken at $10,20,30,40$, and $50 \mathrm{~min}$. Ionophore A23187 $(1 \mu \mathrm{M})$ was added to the flasks indicated at $30 \mathrm{~min}$ to stimulate phospholipase activity. Data are given as mean \pm SEM, $n=6$.

\section{Discussion}

In these experiments we have shown that vascular endothelial cells are very sensitive to damage by $\mathrm{H}_{2} \mathrm{O}_{2} \cdot \mathrm{H}_{2} \mathrm{O}_{2}$ potently blocked $\mathrm{PGI}_{2}$ formation presumably by inhibiting cyclooxygenase. This effect occurred at a dose $(35 \mu \mathrm{M})$ and time course (>1 min) much different from that seen for cell membrane disruption. When either ${ }^{51} \mathrm{Cr}$ or $\mathrm{LDH}$ release was monitored, doses greater than $500 \mu \mathrm{M} \mathrm{H} \mathrm{H}_{2} \mathrm{O}_{2}$ and exposures of $60 \mathrm{~min}$ were necessary to produce the increases indicative of cell membrane damage. Similar inhibition of $\mathbf{P G I}_{2}$ formation was also observed when cells were incubated with the superoxidegenerating system, xanthine plus xanthine oxidase. The damaging species produced by this generating system appeared to be $\mathrm{H}_{2} \mathrm{O}_{2}$ and not superoxide itself in that catalase but not superoxide dismutase was protective.

Over the dose range studied, $\mathrm{H}_{2} \mathrm{O}_{2}$ produced a rapid inhibition of cyclooxygenase. Maximum inhibition was achieved

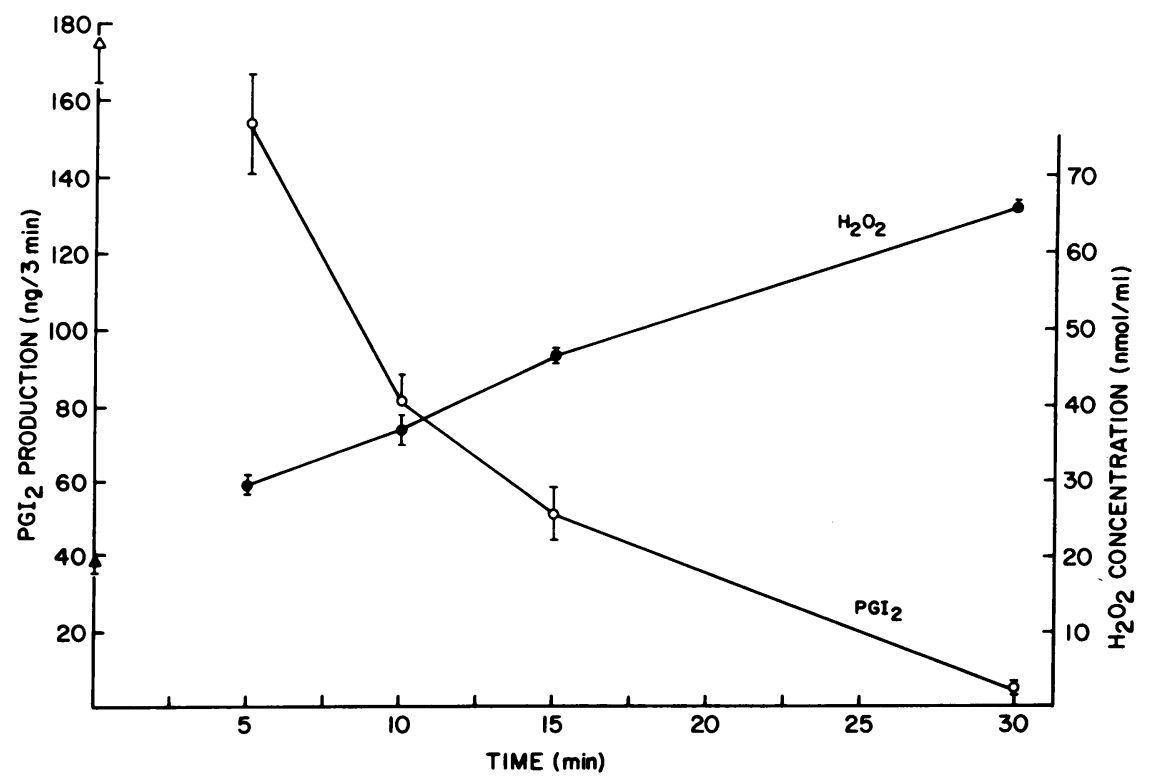

Figure 6. The relationship between formation of $\mathrm{H}_{2} \mathrm{O}_{2}$ by xanthine plus xanthine oxidase and the extent of inhibition of $\mathrm{PGI}_{2}$ formation as a function of time. Cells were preincubated for the times given with xanthine plus xanthine oxidase, rinsed, and incubated with arachidonic acid as described in Fig. 5. Data on the ordinate represent basal $\mathrm{PGI}_{2}$ production $(\Delta)$ and $\mathrm{PGI}_{2}$ synthesis in response to $5 \mu \mathrm{M}$ arachidonic acid $(\Delta)$. Data are given as mean \pm SEM, $n=3$. 
Table I. Prostaglandin Formation

\begin{tabular}{lcc}
\hline Buffer & \multicolumn{1}{l}{$\mathrm{PGI}_{2}$} & $\mathrm{PGE}_{2}$ \\
\hline & $n g / 10 \mathrm{~min}$ & $n g / 10 \mathrm{~min}$ \\
Control & $7.6 \pm 0.2$ & $6.1 \pm 0.4$ \\
Ionophore A23187 & & \\
$\quad(0.5 \mu \mathrm{M})$ & $116 \pm 2$ & $108 \pm 6$ \\
$\mathrm{PGH}_{2}(5 \mu \mathrm{g} / \mathrm{ml})$ & $61.9 \pm 0.8$ & $2,180 \pm 30 \ddagger$ \\
$\mathrm{H}_{2} \mathrm{O}_{2}(50 \mu \mathrm{M})$ & $5.5 \pm 0.3$ & $2.0 \pm 0.3$ \\
$\mathrm{H}_{2} \mathrm{O}_{2}+$ ionophore A23187 & $51.7 \pm 1.4^{*}$ & $41.5 \pm 2.1^{*}$ \\
$\mathrm{H}_{2} \mathrm{O}_{2}+\mathrm{PGH}_{2}$ & $75.2 \pm 1.3$ & $2,190 \pm 56 \ddagger$ \\
\hline
\end{tabular}

Confluent monolayers of endothelial cells were pretreated with buffer or buffer containing $50 \mu \mathrm{M} \mathrm{H}_{2} \mathrm{O}_{2}$ for $10 \mathrm{~min}$ and then rinsed. Additions as indicated were made and the amount of $\mathrm{PGI}_{2}$ and $\mathrm{PGE}_{2}$ produced during a 3-min incubation period determined by GCMS analysis. Data are given as mean $\pm \mathrm{SEM}, n=7$.

* Values significantly different from ionophore A23187 alone $(P<0.01)$.

† Represents nonenzymatic breakdown of excess $\mathrm{PGH}_{2}$.

within $1 \mathrm{~min}$. No further effects were seen although $\mathrm{H}_{2} \mathrm{O}_{2}$ concentrations remained relatively high during the first 30 min of incubation ( $30 \%$ of initial concentration). In those experiments in which xanthine plus xanthine oxidase was used (see Fig. 6), progressive inhibition of $\mathrm{PGI}_{2}$ formation accompanied accumulation of $\mathrm{H}_{2} \mathrm{O}_{2}$ in the medium. Based on the rapid time course of $\mathrm{PGI}_{2}$ inhibition noted after exposure of endothelial cells to fixed concentrations of $\mathrm{H}_{2} \mathrm{O}_{2}$ (Fig. 2), the progressive decrease in cyclooxygenase activity seen in Fig. 6 would appear to be due to the progressively increasing levels of $\mathrm{H}_{2} \mathrm{O}_{2}$. The kinetics of $\mathrm{H}_{2} \mathrm{O}_{2}$-induced damage must be exceodingly complex in exhibiting both early events (cyclooxygenase inactivation) and late events (membrane disruption) with the exact time course being governed by actual intracellular $\mathrm{H}_{2} \mathrm{O}_{2}$ concentrations in the face of falling extracellular levels. In addition, if the ultimate toxic agent is the hydroxyl radical $\left(\mathrm{OH}^{\circ}\right)$, then regulation of its formation by peroxidases and by the availability of $\mathrm{Fe}^{2+}$ would be important. The system is obviously even more complicated because susceptability and kinetics may vary among individual compartments within the cell. Interestingly, endothelial cells have been shown to contain two distinct pools of cyclooxygenase which respond differently to exogenous versus endogenous arachidonate (29). Finally the role of protective systems such as catalase and the glutathione redox cycle $(3,30)$ in regulating peroxide levels must be considered.

In contrast to reports by others (31) that demonstrate either direct stimulation of $\mathrm{PGI}_{2}$ formation by $\mathrm{H}_{2} \mathrm{O}_{2}$, or $\mathrm{H}_{2} \mathrm{O}_{2}$ mediated stimulation of $\mathrm{PGI}_{2}$ formation by activated neutrophils (32), we found no stimulatory effects of $\mathrm{H}_{2} \mathrm{O}_{2}$ on basal production of $\mathrm{PGI}_{2}$ by resting monolayers (Table I). Different experimental procedures could conceivably result in large variations in endogenous peroxide levels and therefore major differences in cellular peroxide tone. It is well known that such differences in peroxide tone can lead to significant differences in cellular metabolism of arachidonic acid (33-35), ultimately resulting in stimulation of cyclooxygenase activity as previously described $(31,32,35)$ or in inhibition of this enzyme as our present data indicate. The ambient peroxide level in a cell is determined by a number of factors including the glutathione redox cycle $(3,30)$. The kinetics and capacity of this system to detoxify peroxides may ultimately determine the overall concentration and thus effect of exposure to radical generating species. In previous studies in isolated perfused rabbit aorta, we have in fact observed both stimulation of prostaglandin production by low doses of 15-hydroperoxyarachidonate ( 2 $\mu \mathrm{g} / \mathrm{ml})$ and inhibition by higher concentrations $(10 \mu \mathrm{g} / \mathrm{ml})$ (18). Additionally, a regulatory role for lipid peroxides has been proposed where constant low levels of these compounds are required for cyclooxygenase activity (35). Therefore it may be difficult to compare data between experiments where exogenous peroxides are added if the status of endogenous protective systems is unknown.

$\mathrm{H}_{2} \mathrm{O}_{2}$ may also have other effects on intact cells which lead to elevated prostaglandin synthesis. For example, in a recent report (31), $\mathrm{H}_{2} \mathrm{O}_{2}$ treatment results in rapid disturbance in $\mathrm{K}^{+}$ flux with a time course which resembles the pulse of prostaglandin synthesis described. The effect of $\mathrm{H}_{2} \mathrm{O}_{2}$ on the flux of other ions such as $\mathrm{Ca}^{2+}$ has not been investigated. A net $\mathrm{Ca}^{2+}$ influx occurring along with $\mathrm{K}^{+}$efflux would certainly activate phospholipase activity, arachidonic acid release, and subsequent prostaglandin synthesis.

Metabolism of endogenous or exogenous arachidonic acid leads to inactivation of both cyclooxygenase and prostacyclin synthase, presumably due to overproduction of free radicals $(19,36)$. Of the two enzymes, cyclooxygenase, on the one hand, appears to be particularly sensitive to such inhibition. On the other hand, addition of exogenous lipid peroxides (15hydroperoxyarachidonate) preferentially inactivates $\mathrm{PGI}_{2}$ synthase (18). The exact mechanism for inactivation of these enzymes is unknown. However, activity of the peroxidase component of the cyclooxygenase appears to be involved (19). Enzymatic reduction of prostaglandin $\mathrm{G}_{2}$ to $\mathrm{PGH}_{2}$ by this peroxidase has been shown to produce a radical which is destructive towards cyclooxygenase activity (19). Although the identity of this radical remains controversial (37), the highly reactive $\mathrm{OH}^{*}$ has been implicated $(19,38)$. Production of $\mathrm{OH}^{*}$ radicals may also be involved in the inactivation of cyclooxygenase by $\mathrm{H}_{2} \mathrm{O}_{2}$. Certainly $\mathrm{OH}^{*}$ can be easily produced from $\mathrm{H}_{2} \mathrm{O}_{2}$ by several routes including the Fenton reaction catalyzed by $\mathrm{Fe}^{2+}(5)$, by heme proteins, and possibly by the peroxidase component on cyclooxygenase itself $(37,39)$. In addition, secondary radicals such as lipid radicals may also play a role in these effects. Inhibition by $\mathrm{H}_{2} \mathrm{O}_{2}$ appears to involve covalent destruction of enzyme protein as recovery of activity requires 2-4 $\mathrm{h}$ of incubation in complete medium and is inhibited by protein synthesis inhibitors (Barchowsky, A., A. R. Whorton, and R. S. Kent, unpublished data).

In the present study, exogenous $\mathrm{H}_{2} \mathrm{O}_{2}$ inhibited cyclooxygenase exclusively with no measurable effect on $\mathrm{PGI}_{2}$ synthase. It is possible that the polarity of the parent peroxide dictates which enzyme is inactivated by radical attack. This may be determined in part by unique requirements for the interaction of various peroxides with the enzyme protein. Alternatively, compartmentation and availability of these enzymes to peroxides of differing polarity may be important. From the present study and from our previous work, it appears that polar peroxides such as $\mathrm{H}_{2} \mathrm{O}_{2}$ selectively inhibit cyclooxygenase whereas lipophilic peroxides such as 15-hydroperoxyarachidonic acid selectively inhibit $\mathrm{PGI}_{2}$ synthase particularly at low levels. Thus differential inactivation of the enzymes of the arachidonic acid cascade by various peroxides may have important regulatory effects on both the amount and pattern of prostaglandins produced by a tissue. 
In a recent report (31), $\mathrm{H}_{2} \mathrm{O}_{2}$ was shown to block specifically ionophore $\mathrm{A} 23187$-stimulated $\mathrm{PGI}_{2}$ production. This effect was found only to occur at high $\mathrm{O}_{2}$ tension. No effect of 100 $\mu \mathrm{M} \mathrm{H}_{2} \mathrm{O}_{2}$ was seen on cells incubated in air, and no information regarding the site of inhibition was given. From these data it is not possible to determine potential inhibitory effects of $\mathrm{H}_{2} \mathrm{O}_{2}$ on phospholipase activity. In contrast, our results from experiments done with cells incubated in air indicate that $\mathrm{H}_{2} \mathrm{O}_{2}$ inhibits ionophore $\mathrm{A} 23187$-stimulated $\mathrm{PGI}_{2}$ production at similar doses and under similar conditions as found for inhibition of the cyclooxygenase. However, because we found no alteration in the amount of labeled products released after ionophore A23187 stimulation, an effect of $\mathrm{H}_{2} \mathrm{O}_{2}$ phospholipase activity is doubtful.

As has been shown in a number of studies, endothelial cells are directly damaged by $\mathrm{H}_{2} \mathrm{O}_{2}(1-3)$. These cytolytic actions of $\mathrm{H}_{2} \mathrm{O}_{2}$ require treatment for up to $60 \mathrm{~min}$ at doses in the range of $1 \mathrm{mM}$. Data from our experiments on the release of ${ }^{51} \mathrm{Cr}$ suggest that a critical level of damage must be reached and that beyond this threshold ${ }^{51} \mathrm{Cr}$ release increases rapidly. Thus endothelial cells appear to be able to protect their membranes from damage resulting from high levels of peroxides for up to $60 \mathrm{~min}$. Other cytotoxic effects that are more subtle and not lethal are evident at lower levels of $\mathrm{H}_{2} \mathrm{O}_{2}$ and after shorter exposures. For example, $\sim 40 \%$ of intracellular LDH activity is lost during the first 30 min of treatment with $1 \mathrm{mM} \mathrm{H} \mathrm{H}_{2}$. Doses of $\mathrm{H}_{2} \mathrm{O}_{2}$ below $100 \mu \mathrm{M}$ have also been observed to stimulate purine release and $\mathrm{K}^{+}$efflux from endothelial cells with a time course of a few minutes (31). In addition, the capacity to synthesize $\mathrm{PGI}_{2}$ is rapidly lost at low doses of $\mathrm{H}_{2} \mathrm{O}_{2} \quad\left(\mathrm{IC}_{50}=35 \mu \mathrm{M}\right)$. This may be particularly significant in a variety of vascular conditions including atherosclerosis and aging where oxidative cellular damage may be severe enough to inhibit arachidonic metabolism, yet not result in cell membrane disruption and death.

\section{Acknowledgments}

The authors wish to thank Dr. John Pike of the Upjohn Co. for generously supplying deuterated 6-keto-PGF $1 \alpha$.

This work was supported in part by National Institutes of Health grants AG-02868 and HL-31125 and by a grant from the Burroughs Wellcome \& Co., Research Triangle Park, NC. Dr. Whorton was supported by Research Career Development Award HL-00857.

\section{References}

1. Sacks, T., C. F. Moldow, P. R. Craddock, T. K. Bowers, and H. S. Jacob. 1978. Oxygen radicals mediate endothelial cell damage by complement-stimulated granulocytes. An in vitro model of immune vascular damage. J. Clin. Invest. 61:1161-1167.

2. Weiss, S. J., J. Young, A. F. LoBuglio, A. Slivka, and N. F. Nimel. 1981. Role of hydrogen peroxide in neutrophil-mediated destruction of cultured endothelial cells. J. Clin. Invest. 68:714-721.

3. Harlan, J. M., J. D. Levine, K. S. Callahan, B. R. Schwartz, and L. A. Harker. 1984. Glutathione redox cycle protects cultured endothelial cells against lysis by extracellularly generated hydrogen peroxide. $J$. Clin. Invest. 73:706-713.

4. Bishop, C. T., J. D. Crapo, and B. A. Freeman. 1984. Extracellular release of hydrogen peroxide by cultured endothelial cells. Clin. Res. 32:527a. (Abstr.)

5. Babior, B. 1984. The respiratory burst of phagocytes. J. Clin. Invest. 73:599-601.
6. Mazzone, T., M. Jensen, and A. Chait. 1983. Human arterial wall cells secrete factors that are chemotactic for monocytes. Proc. Natl. Acad. Sci. USA. 80:5094-5097.

7. Pryor, W. A. 1982. Free radical biology: xenobiotics, cancer and aging. Ann. N.Y. Acad. Sci. 393:1-22.

8. Harman, D. 1981. The aging process. Proc. Natl. Acad. Sci. USA. 78:7124-7128.

9. Harlan, J. M., P. D. Killen, L. A. Harker, and G. E. Striker. 1981. Neutrophil-mediated endothelial injury in vitro. Mechanisms of cell detachment. J. Clin. Invest. 68:1394-1403.

10. Armstrong, J. M., N. Lattimer, S. Moncada, and J. R. Vane. 1978. Comparison of the vasodepressor effects of prostacyclin and 6oxo-prostaglandin $F_{1 \alpha}$ with those of prostaglandin $E_{2}$ in rats and rabbits. Br. J. Pharmacol. 62:125-130.

11. Czervionke, R. L., J. B. Smith, G. L. Fry, J. C. Hoak, and D. L. Haycraft. 1979. Inhibition of prostacyclin by treatment of endothelium with asprin: correlation with platelet adherence. J. Clin. Invest. 63:1089-1092.

12. Eldor, A., D. J. Falcone, D. P. Hajjar, C. R. Minick, and B. B. Weksler. 1981. Recovery of prostacyclin production by deendothelialized rabbit aorta: critical role of neointimal smooth muscle cells. J. Clin. Invest. 67:735-741.

13. Johnson, A. R., W. Campbell, D. Levine, and W. Schulz. 1983. Influence of prostacyclin on endothelial cell injury. Fed. Proc. 42:772. (Abstr.).

14. Hajjar, D. P., B. B. Weksler, D. J. Falcone, J. M. Hefton, K. Tack-Goldman, and C. R. Minick. 1982. Prostacyclin modulates cholesterol ester hydrolase activity by its effect on cyclic adenosine monophosphate in rabbit aortic smooth muscle cells. J. Clin. Invest. 70:479-488.

15. Huttner, J. J., E. T. Gwebu, R. V. Panaganamala, G. E. Milo, D. G. Cornwell, H. M. Sharma, and J. C. Geer. 1977. Fatty acids and their derivatives: inhibitors of proliferation in aortic smooth muscle cells. Science (Wash. DC). 197:289-291.

16. Sinzinger, H., K. Silberbauer, M. Winter, and P. Clopath. 1979. Effects of experimental atherosclerosis on prostacyclin $\left(\mathrm{PGI}_{2}\right)$ generation in arteries of miniature swine. Artery. 5:448-462.

17. Dembinska-Kiec, A., W. Rucker, and R. S. Schonhofer. 1979. Atherosclerosis decreased prostacyclin formation in rabbit lungs and kidneys. Prostaglandins. 17:831-838.

18. Kent, R. S., B. B. Kitchell, D. G. Shand, and A. R. Whorton. 1981. The ability of vascular tissue to produce prostacyclin decreases with age. Prostaglandins. 21:483-490.

19. Egan, R. W., J. Paxton, and F. A. Kuehl, Jr. 1976. Mechanism of irreversible self-deactivation of prostaglandin synthetase. J. Biol. Chem. 251:7329-7335.

20. Spector, A. A., T. L. Kaduce, J. C. Hoak, and R. L. Czervionke, 1983. Arachidonic acid availability and prostacyclin production by cultured human endothelial cells. Arteriosclerosis. 3:323-331.

21. Kent, R. S., S. L. Diedrich, and A. R. Whorton. 1983. Regulation of vascular prostaglandin synthesis by metabolites of arachidonic acid in perfused rabbit aorta. J. Clin. Invest. 72:455-465.

22. Whorton, A. R., B. J. Sweetman, and J. A. Oates. 1979. Application of high performance liquid chromatography and gas chromatography-mass spectrometry to analysis of prostaglandin $E_{1}$ in biological media. Anal. Biochem. 98:455-463.

23. Jaffe, E. A., R. L. Nachman, C. G. Becker, and C. R. Minick. 1973. Culture of human endothelial cells derived from umbilical veins. J. Clin. Invest. 52:2745-2756.

24. Whorton, A. R., S. L. Young, A. Barchowsky, and R. S. Kent. 1983. Mechanism of bradykinin-stimulated prostacyclin synthesis in porcine aortic endothelial cells. Biochim. Biophys. Acta. 712:79-87.

25. Thurman, R. G., H. G. Ley, and R. Scholz. 1972. Hepatic microsomal ethanol oxidation. Hydrogen peroxide formation and the role of catalase. Eur. J. Biochem. 25:420-430.

26. Kornberg, A. 1955. Lactic dehydrogenase of muscle. Methods Enzymol. 1:441-443. 
27. Bradford, M. 1976. A rapid and sensitive method for the quantification of microgram quantities of protein utilizing the principle of protein dye binding. Anal. Biochem. 72:248-254.

28. Pearson, J. D., J. S. Carleton, and J. L. Gordon. 1980. Metabolism of adenine nucleotides by ectoenzymes of vascular endothelial and smooth-muscle cells in culture. Biochem. J. 190:421-429.

29. Willems, C., P. G. De Groot, G. A. Pool, M. S. Gonsalvez, W. G. van Aken, and J. A. van Mourik. 1982. Arachidonate metabolism in cultured human vascular endothelial cells. Evidence for two prostaglandin synthetic pathways sensitive to acetylsalicylic acid. Biochim. Biophys. Acta. 713:581-588.

30. Nathan, C. F., B. A. Arrick, H. W. Murray, N. M. DeSantis, and Z. A. Cohn. 1981. Tumor cell anti-oxidant defenses. Inhibition of glutathione redox cycle enhances macrophage-mediated cytolysis. $J$. Exp. Med. 153:766-782.

31. Ager, A., and J. L. Gordon. 1984. Differential effects of hydrogen peroxide on indices of endothelial cell function. J. Exp. Med. 159:592-603.

32. Harlan, J. M., and K. S. Callahan. 1984. Role of hydrogen peroxide in the neutrophil-mediated release of prostacyclin from cultured endothelial cells. J. Clin. Invest. 74:442-448.

33. Hemler, M. E., H. W. Cook, and W. E. M. Lands. 1979.
Prostaglandin biosynthesis can be triggered by lipid peroxides. Arch. Biochem. Biophys. 193:340-345.

34. Hemler, M. E., and W. E. M. Lands. 1980. Evidence for a peroxide-initiated free radical mechanism of prostaglandin biosynthesis. J. Biol. Chem. 255:6253-6261.

35. Kulmacz, R. J., and W. E. M. Lands. 1983. Requirements for hydroperoxide by the cyclooxygenase and peroxidase activities of prostaglandin synthase. Prostaglandins. 25:531-540.

36. Ham, E. A., R. W. Egan, E. E. Soderman, P. H. Gale, and F. A. Kuehl, Jr. 1979. Peroxidase-dependent deactivation of prostacyclin synthetase. J. Biol. Chem. 254:2191-2194.

37. Kalyanaraman, B., R. P. Mason, B. Tainer, and T. E. Eling. 1982. The free radical formed during the hydroperoxide-mediated deactivation of ram seminal vesicles is hemoprotein-derived. J. Biol. Chem. 257:4764-4768.

38. O'brien, P. J., and C. G. Hulett. 1980. Hydroxyl radical involvement in the luminol chemiluminescence from the reaction of (20:4) with sheep vesicular gland microsomes. Prostaglandins. 19:683691.

39. Kuehl, F. A., J. L. Humes, M. L. Torchiana, E. A. Ham, and R. W. Egan. 1979. Oxygen-centered radicals in inflammatory processes. Adv. Inflammation Res. 1:419-430. 